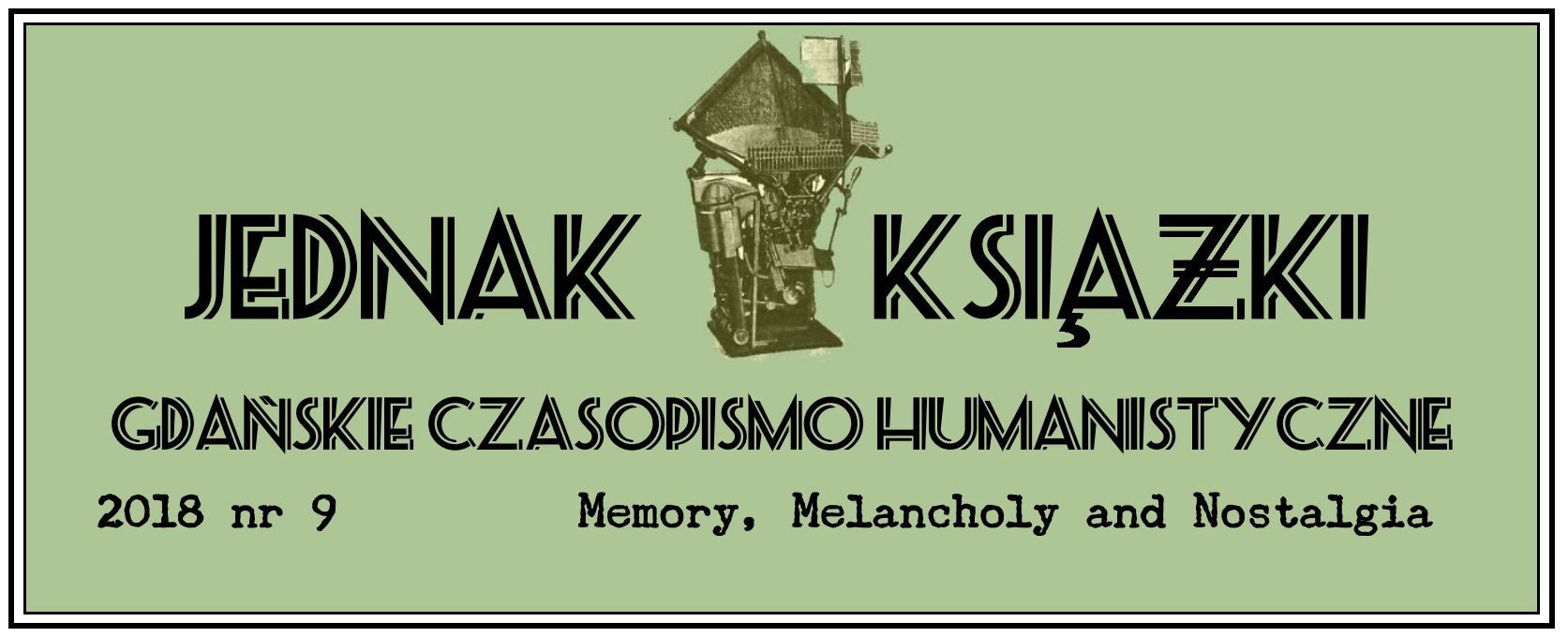

\title{
STUDIESS
}

\section{OPENING THE DOOR OF THE HAUNTED HOUSE: AN INQUIRY OF THE NOSTALGIC EXPERIENCE}

\author{
POLINA GOLOVÁTINA-MORA \\ Universidad Pontificia Bolivarianain in Medellín (Colombia) \\ Faculty of Social Communication-Journalism
}

"Forget the staircase. It's all about yourself."

(Sakharov 1989)

\section{Introduction}

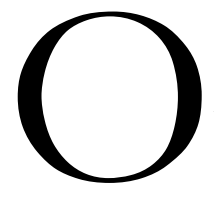

ur knowledge is a complex mixture of various experiences heard, read, lived or imagined. As a person marks their own experiences with their encounters with material objects, persons, smells and sounds, memory gets grounded and marked with them as well. Following encounters with the markers bring back the memories associated with them. These markers, as Trubina demonstrates in more details, being inevitably shared with 
others, make "personal memories a part of the social working of memory, and turn the person to a member of a certain memory community" (Trubina 2011: 27). Yet, as Trubina argued, it is an individual who remembers. This thought makes me turn primarily to the individual experiences of nostalgia as opposed to nostalgia as a collective phenomenon or a tool of mass manipulation.

For this purpose, I rely on the narrative inquiry method as a form of preserving and passing one's memory and through that making sense of one's own reality (Clandinin 2013). The departure point for my analysis combined autoethnography (Chang 2009; Denzin 2014) and fiction writing (Leavy 2013), as there are multiple elements in the data that resonate with my personal experience, all of which I bring together for my interpretations. The article explores the function of nostalgia employing interpretative analysis of the personal short stories, mainly The Urbanisation, selected personal journal entries and blog entries of a woman traveller and immigrant to Colombia. I also used semi-structured interviews with other female immigrants in Colombia put in the context of cultural, psychological and philosophical studies of nostalgia (Boym 2001; Casey 1987; Davis 1979) that I discussed in more details elsewhere (Golovátina -Mora 2016), memory and borderlands identity (Anzaldúa 1987), various literary and cinematic works on memory.

\section{The Haunted House of the Mind}

A house and home have a significant part in the human imaginary. First, a person would always search for a shelter and long for a secure place. Such place would become an association for the sense of belonging, Selfness, and wholeness. A house is an archetypal image: its parts may signify different levels of recognition of Self while a stairway often signifies a search of one's path and altogether exploration of one's personality (Jung 2003: Ch. VII).

Apart from that, memory itself with its complex relations between the individual and the collective can be compared to a house. A house is both private and shared with other living beings, objects and emotions. It is both a shelter (a place to enter and hide) and a place to go out from to the outer world. It is structured and to an extent organized as it always has a certain form and yet it represents an accumulation of the material and spiritual that may be in the chaotic state. Therefore, the house would always present both well-known and the unknown to be discovered. It is a unity in itself and yet a complex compound entity. Together with memory or a personality the house can be compared to a kaleidoscope - a device that combines a chance with well thought organization, the single whole and the compound structure. Even the etymology of the 
word kaleidoscope reflects the nature of the memory: exploration of the beautiful shapes (of Self) or random thoughts that under certain perspective show its richness and beauty.

Another interesting analogy that was brought up by one of my interviewees is a Rubik's Cube. The interviewee used this analogy to describe new experience and life in a new place as it must be: “...not the series of disappointments but a Rubik's Cube that you find intriguing to collect. At first, you may like the system of the orange colour, and then you may decide to change it to white or green, but nonetheless you remain happy with the entire system." Developing the metaphor, I can define memory as an intellectual time consuming game of bringing together pieces that may or may not come together depending on the desire, skill and dedication of the involved player. The system consists of both the Rubik's Cube itself and the player.

Memories, perhaps for their spontaneous, sometimes random and persistent appearance, are often described as haunting. While the examples are quite abundant, confession of cutter Alan in The Final Cut (Naim 2004) would be a good illustration: "Then you know what it's like to be haunted. One memory... one single incident has made me who I am. It won't leave me be...”. It is one's Self who really haunts the house, while memories only provide hints and reminders and pose the burning questions.

Memory, according to Trubina (2011: 25-27), unites cognitive and normative dimensions. This would always turn memory to a haunted house and haunting phantasms themselves and nostalgia to a cognitive and moral mechanism of securing the interest in the memory. As Colombian writer Rosero concluded in his short story "La Casa" ("A House"): "I guess it is impossible to escape my own tyranny for good as I am also inside myself" (2013: 53). If there is no escape from one's memory and from one's Self, what can ease the suffering? Immersing in the house and exploring it with acknowledgment and curiosity would allow one to move freely in, out, over and around it: "Go slowly through the house. Be polite, introduce yourself, so it can introduce itself to you." (Wells 2003).

\section{Home, Belonging and Borderlands}

Boym (2001) defines nostalgia as a shared with all human-being longing for sharing one's intimacy. It makes it a painful experience, which is reflected in the etymology of the word: a painful comeback. It is paradoxical and somewhat masochist, as blogger Vizovskaia described her nostalgia (2014). A person, a community or a culture are never static but develop as long as they live. Travelling and border-crossing are in the nature of the mind and identity of any person and not necessarily of an immigrant (Anzaldúa 1987). Yet for physiological, psychological and 
cognitive reasons, limitation is also part of the nature. Therefore, longing for the new frontiers would always come together with longing for home and create, so, a feeling of dissatisfaction and unease.

Longing for sharing coincides with the definition of home provided by Hedetoft and Hjort: "Where we belong, territorially, existentially, and culturally, where own community is... where we can identify our roots, and where we long to return to... a significant determinant of identity, that elusive but still real psychological state of being in sync with oneself under given external circumstances.” (2002: vii). Understood like that, longing for home is, then, an expression of human need for love and belonging (Maslow 1954). Russian poet Grebenschikov, for instance, defined love as "a method of coming back home." (1984b).

It is never an actual place, but rather a memory community (Trubina 2011). While the chances of finding home at one's birth place may be better, finding home would be always a frustrating process taking into account a complex, layered (Nussbaum 1994) or a mestiza (Anzaldúa 1987) nature of the individual and even collective identity. Sharing will be always a problem as one's home if found will not be home for another person.

When I asked my interviewees to what exactly they ever felt nostalgic, they described similar feelings and objects of nostalgia. They were about home. While a particular place and country were described, home was more of a temporal-spatial and relational setting. Objects of their nostalgia were their personal experiences, childhood and youth, freedom of unmarried life and people - family and friends. Overall, they were everything that the new environment lacked. I share this emotion and still struggle answering the question that people often ask me in Colombia, if I miss my homeland. The answer should be a long and complicated life story, a story of relations, joys and worries.

It is good here. There are seasons, and the beauty of my city sparkles with different colours in different seasons. Here is my youth, my childhood, my stories, my experience, my mistakes, my festivities, my lessons. Here a lot is known and almost everything is clear. The city has its soul and I am part of it. ... The fairy-tales we grew up with, the songs we listened to, beer we drank, lessons we learnt, situations we lived through - all of them are ours. And there they are different. This does not allow me to come closer to them. I understand that people that I know here won't be there. But I do not need all that to be of the other kind,

the blogger wrote in her post after visiting her hometown a year after moving to Colombia (Vizovskaia 2015). Trying to understand why I do not feel at home around the local people I came to realise that they simply are not my family or my friends. It may sound ridiculous, but as we can see, the experience is shared and confirms Boym's statement that nostalgia "goes beyond individual psychology.” (2001: xv). 
The memory community implies borders and a certain exclusion: as for example in the personal short story The Urbanisation, I describe it as a fairy settlement separated from the people's world. A couple of travellers I interviewed told me that the thing they missed most in their long travels is not being around their friends - people whom you do not need to explain your jokes to, your sayings or your word choice. Yet, they confirmed they do not mean their compatriots altogether: "When it happens that I meet someone, let's say an American, who makes the same type of jokes as I do, I just want to hug him.” Being in a country different from one's "native" place does not automatically mean lack of understanding. One interviewee told me she does not have nostalgia but just occasional associations or memory flashes. New acquaintances, experiences and memories replace the old ones.

\section{Nostalgia: A Denial, a Reappraisal or a Critical Affirmation?}

Inability to comprehend one's own Self right away in all its totality or know completely another person's mind, cultural clashes and complex and paradoxical nature of memory and nostalgia itself make nostalgia a self-nourishing phenomenon. That life is unsatisfying is a common cliché one can find in popular culture (Allen 2011), scholarship (Tuan 1998) or in everyday talks, as several of my interviewees pointed it out. Is there any escape from nostalgia then? First, we need to clarify once again what an escape is. As I discussed elsewhere (Golovátina-Mora 2014), everything would depend on the outcome of the escape: one can get lost and never recover or one can use an escape as a form of therapy and as a source of deeper knowledge of oneself and the world around.

Is nostalgia a "denial of the painful present" as Paul declared in Midnight in Paris (Allen 2011)? In a way, yes. It is a product of the lost control, speed of changes and the changes themselves as various authors defined it (Boym 2001; Davis 1979). It is a reaction to all above -mentioned dissatisfactions but it is human as memory or emotions. The film Midnight in Paris (Allen 2011) is dedicated to nostalgia. Two characters, Gil and Adriana, dissatisfied with their presents, personify two opposite ways of dealing with nostalgia. Adriana happily stays in her Golden Age - La Belle Époque while Gil comes to realisation that "the present is always going to seem unsatisfying because life itself is unsatisfying... it's my job as a writer to try and come up with reasons why despite life being tragic and unsatisfying, it's still worth it." (Ibid.). They both have courage to immerse in the past. But Gil critically and thoughtfully revises it while enjoying it, uses it to learn more about himself, people and places around him and employs the acquired 
knowledge to improve his present work and life. He does not ignore nor praises it blindly but cooperates with the past as with his equal. His initial affection to the past served as a stimulus to maintain his curiosity and interest in it. "Sometimes you have to travel back in time, skirting the obstacles, in order to love someone," Mayes wrote. (2015: 277).

Blogger Vizovskaia, who in a personal interview confessed that all her posts are about nostalgia, writes in one of her posts: 'Words 'homeland' and 'home' are not meaningless for me, but I had to go far away to understand it." (Vizovskaia 2015). In her earlier post, describing her last days at home before her moving to Colombia, Vizovskaia wrote: "The same way as I was soaking images around me in with every cell of my body in my travelling before, I was trying to remember images of my dear home". (2014). The women I interviewed developed a certain affection for their homeland as a response to uncertainties, commitments they did not experience before, lack of the usual and well known, but what appeared to be especially important was the absence of the memory community that they felt separated from with their emigration. In other words, nostalgia was triggered by abrupt changes and by the lost control over the events. As experienced travellers, nevertheless, who always appreciated changes and novelty and had courage to weather them they understand that changes are inevitable and may be good and that travelling to a place is different from living there. They immerse in their nostalgic experience and learn more about their past by revisiting it and, so, by revisiting themselves. The past with its imperfectness is accepted as part of oneself: "What a fool sage said that creating ties is bad? Maybe it is. But how can one live without them? It means I am made of flesh and blood if I can feel them so strongly. Moreover, I felt I do not want to break them.” (Vizovskaia 2014).

Comparing their past experiences with their absence in present they discover what they like and why, what is good and why exactly so. All the responses I got were quite elaborated with a lot of interest in the question itself. Answers were similar in their structure: "I always thought I do not like x, now I dream about it." As one interviewee told me: "I never liked the way my grandfather talked with all the proverbs and the quotes from the movies and TV programs. I noticed now I sound like my grandpa." This formula presents a revision of the norms and values the interviewees learnt somewhere before: "I hated cold," "I loved the sun," "I thought I would never put that artisan shawl on," "I valued smiles" to name a few.

Contesting these norms, they realise their relativity and start appreciating the beauty of any imperfection. During my last trip to my hometown in winter, I noticed how beautiful the mud is: snow on the road had different shades of grey and traces of the tyres had different patterns. All together they made mud look like laces on display in a fabric store. Boym (2001) described her enjoyment with mineral-water during her visit from emigration. She noted that everyone 
including herself hated that brand for its terrible taste when she lived in the Soviet Union. Another example could be the windy rain, which several interviewees mentioned, which I can relate to myself and to which I even dedicated my earliest stories to (Of Golden Fairy). Rainy evenings that in such tropical country as Colombia are considered cold bring memories of the city transport stops where you could wait long enough to get cold. Cold or fresh wind for a moment takes one's breath away and makes one feel lonely and long for one's cosy apartment and tea and at the same time, as unsatisfied north wind in the movie Chocolat (Hallström 2000), feel unity with freedom and infinity of the elements.

Being outside of home my interviewees turned to tourists in their home, which provoked fits of nostalgia and yet allowed them to look from a different perspective at their home. Vizovskaia describes nostalgic experiences as tranquil happiness (2013) or happy sadness (2014), as it helps to explore different sides of one's Self, emotions and thoughts one can experience or the life one can build.

This creates nostalgia to memory itself as to a brain stimulating creative process:

I do not want to forget all that, I do not want to forget anything at all! Fortunately, I have a good memory, but sometimes I am horrified I can forget some story, a detail from my life. This would be a disaster. Because my life will be incomplete without any of such story or to be more precise without a memory of it. I am horrified and therefore I try to do everything possible to preserve it in my memory or on paper... A photo can remind you about places and people, but it is more difficult and more important to remember emotions, worries or passions provoked by a certain moment ... If only I could cast in stone of my memory those moments, meetings, songs, sights, letters, locations, emotions, beliefs in myself. In stone! Then my childhood, adolescence and youth, my joys and hopes will remain with me forever. (Vizovskaia 2014).

Inability to keep memory forever causes nostalgia. But if it stays forever it turns into that unsatisfying present: "Would we be so happy about the sun and its warmness if it was always with us?" (Vizovskaia 2014). Partial and imperfect solutions that this author, other interviewees and myself suggest are to write, take photos, talk about them, create a replacement of the memory community with those who share your way of thinking, leave the place for good, go somewhere else to satisfy, for example, the need for seasons, start cooking home food, pursue new and old dreams or revisit one's own childhood with one's own children.

\section{Opening the Door}

After moving to the environment in many aspects quite different from the one I was used to, I started experiencing spontaneous backlashes of memories, some of which I thought were long 
forgotten. While being generally happy, they produced melancholic and nostalgic feelings that caused an increasing depression. Its melancholic nature, as I can better see now after analysing the interviews and my own experience, is the result of the lack of the memory community where I would be understood almost unconditionally. The same way as my interviewees, I had to embrace the memory and immerse in it. To create a correspondence between those inner backlashes and the environment, in other words, re-establish the material anchors that memory and nostalgia require (Boym 2001; Trubina 2011), I act out certain memorial moments, ask more questions about lives or the past of my friends and family, paint and write.

When time allows, I cook. It is not necessarily my grandma's food that on everyday basis could be ethnically neutral. Nor is it necessarily the taste known since my childhood. I make certain dishes for particular memories they evoke: a proud feeling of happiness of helping grandparents and a desire to hear again their voices with making pelmeni or to relive a moment of coming back from school with the smell of golubtsy in the oven or simply of that childish joy about coming meal time.

I listen to the songs and read literature I actually never have read before because of the certain associations that I thought will help me to recreate my memories at best. Sincere simple melody and thoughtful and romantic lyrics of the 1960s bard poetry, for instance, created images of wandering around in the forests and mountains or of sitting in among friends and singing songs around the bonfire. Interestingly, I cannot say I had a real experience of such wandering even though we spent a lot of time outside the city with my parents, nor was it the experience I dreamt to have. As Grebenschikov (1984a) wrote: "I hear the sound of waves that are not even there." It was a combined image based on the movies, personal life experience, stories of good friends and parents. The songs were to help me to become part of the memory and of the soul of a time or a place that I cared for.

Nostalgia became a source of inspiration that unearthed new material for creativity. It slightly changed the area of my academic endeavours and over all helped me to look differently at certain cultural and historical phenomena, pop-culture and art while deepening knowledge about myself. While quite a few stories I wrote were inspired by nostalgic experience, I want to share some excerpts from one story that grew out of the overwhelming memory flashbacks.

Clouding up for several days they finally exploded in a story that was written in an hour as a stream of thought. It brought me an emotional relief but did not make the flashbacks disappear. On the contrary, it urged me to explore my memory and past as well as why I think much about it. It was a happy painful (masochist) experience. 
For some days now, I feel the scent of the warm pine trees as soon as I start thinking about it. It may be though the other way around: I think about it when I feel it. It is warm and it is expanding. I can almost see it, see how it climbs up the trunk of the pine tree joining other smells of the forest. It flows into the warm red pine needles on the grounds that prick your bare feet while you walk on them kicking small pine cones and stumbling over the roots from time to time. Clearly, they crawled out to look at this rising red golden scent. I see the field, it is very hot - it is hotter there than on this walk, and the bright blue sky with almost no clouds. I walk through the forest, appearing simultaneously in three forests. This one is the first. ...

The story is an imaginary walk in three different forests at the same time, which reflects emergence of the images: suddenly without any obvious source that could have caused them or as a long chain reaction well described by Vizovskaia (2014): “...I heard a tune, felt a scent; memories actualised and a sweet tide rolled...” All the images are dreamlike modifications of the real experiences built on the emotions, sounds and scents as a kaleidoscope that the story itself tries to organise in the patterns of a Rubik's Cube.

The story that I left as a diary entry without any edition is a search of one's place, home and the lost community. The title Urbanisation, which occurred on whims right after I finished my writing, seemed appropriate in the context of a common definition of a city as fragmentation of the space and community and as isolation of an individual (Borsdorf and Hidalgo 2009; Simmel 1903). The imagined world stipulated by that "sweet tide" of happy memories of home creates the environment that is difficult to leave.

Suddenly I am in the different forest. It is quiet and freshly humid. Red leafage covers the entire slope. This slope is like a wall, almost vertical, strengthened with the dark tree trunks. These sudden changes of the forests look suspicious. They are too sudden even for our world of emotions. I can't understand completely if I am still there or somewhere else, and I am afraid they are just flashes of memory not even connected to make one story. It means I am human after all.

Waking up from the trance-like experience of the sweet dream that was the result of accumulated intense memory flashes, I started thinking about what it was and why. The scent of pines was a marker of nostalgia that served as a guide or Ariadne's thread to help to get in and out of the past.

The smell of the pines is dissolved by the heated stone and asphalt that comes from the open balcony. Shouting of a street vendor breaks in pieces the last mosquito buzzing, delicate tinkling of droplets on the sisters' beads, crackling sounds of the pine needles and of the wings of dragonflies. There aren't even pines around here - they are miles and miles away. What had ever happened? 


\section{Conclusions}

Nostalgia continues to be overlooked by the formal argument based on positivist rational thought as a negative or at least a useless activity. Yet, as any product of human mind nostalgia is relative. Its outcomes depend a lot on the perspective one takes and on the application. It may create a rosy mist that will not allow one to see one's present problems anymore but not necessarily to disappear in sweet oblivion, it may also mean to focus on what is good and take it as a motivation to explore more of one's life and relations. Like that nostalgia is a memory mechanism that provides more options for one's decision making and so provides conditions for critical revision of one's experience both shared and individual.

Nostalgia helps to create not a sense but the actual continuity in space, time and relations and bring together forgotten pieces of one's past in order to make more sense of one's present existence and, so, give hope for the future. In other words, nostalgia is an irreplaceable mechanism of securing fulfilment of all levels of needs in Maslow's hierarchy to be able to grow into a happy (self-actualised) person. The key to make it work is in what we do with nostalgia. Opening the door to the haunted house might do some good after all.

\section{ACKNOWLEDGEMENTS}

All articles published in the issue are the revised texts based on lectures delivered at the $4^{\text {th }}$ International Interdisciplinary Memory Conference in Gdansk "Memory, Melancholy and Nostalgia" (17-18 Semptember, 2015).

\section{SUMMARY}

\section{Opening the Door of the Haunted House: An Inquiry of the Nostalgic Experience}

The article explores nostalgia as a cognitive and affective mechanism of memory aimed at the restoration and healing of one's Self and developing knowledge of one's Self by means of involving oneself in the individual or collective past. Employing method of narrative inquiry with the elements of autobiographical inquiry and fiction writing, the article focuses primarily on the 
individual nostalgic experience unlike nostalgia as a collective phenomenon. The article relies on interpretative analysis of the author's short stories, selected diary entries, interviews with female immigrants in Colombia and travel blog entries in the broader context of the sociological, psychological and philosophical studies of memory and nostalgia and literary and cinematic works that explore the relevant topics.

\section{KEYWORDS}

Emigration, memory, narrative inquiry, Self-knowledge, Soviet childhood

\section{BIBLIOGRAPHY}

Anzaldúa, Gloria. 1987. Borderlands/La Frontera: The New Mestiza. San Francisco: Spinsters/Aunt Lute.

Borsdorf, Axel and R. Hidalgo. 2009. "The Fragmented City.” The Urban Reinventors Online Journal 3. "The Right to the City: The Entitled and the Excluded." The Urban Reinventors Paper Series. Online:

https://www.uibk.ac.at/geographie/personal/borsdorf/pdfs/borsdorfhidalgourbanreinventors.pdf. Accessed February 05, 2018.

Boym, Svetlana. 2001. The Future of Nostalgia. New York: Basic Books.

Casey, Edward. 1987. The World of Nostalgia. Man and World. 20: 361-384.

Chang, Heewon. 2009. Autoethnography as Method. Walnut Creek, CA: Left Coast Press.

Chocolat. Directed by Lasse Hallström. USA, UK, 2000. DVD.

Clandinin, D. Jean. 2013. Engaging in Narrative Inquiry. Walnut Creek, CA: Left Coast Press.

Davis, Fred. 1979. Yearning of Yesterday: A Sociology of Nostalgia. New York: The Free Press.

Denzin, Norman. 2014. Interpretative Autoethnograpy. Thousand Oaks, CA: Sage.

Golovátina-Mora, Polina. 2014. “A Forced Road to a No-Place: Escapism as a Form of Inner Emigration.” In A. Mazurkiewicz (Ed.). Studia Historica Gedanensia 5. Od Exsilii do Exile. Praymus w migracjach: 40-57.

Golovátina-Mora, Polina. 2016. "Remembering the Future or in Search for the "Marvellous Far"." In W. Owczarski, Z. Ziemann and A. Chalupa (Eds). Memory: Forgetting and Creating. Gdansk, Sopot: Wydawnictwo UG: 210-223.

Grebenshikov, Boris. 1984a. "Elektrichestvo." [Song]. In the Album Den' Serebra.

Grebenshikov, Boris. 1984b. "Master Bo.” [Song]. In the Album Den' Serebra. 
Hedetoft, Ulf and M. Hjort, eds. 2002. The Postnational Self: Belonging and Identity. Minneapolis: University of Minnesota Press.

Jung, Carl G. (2003). Vospominania, Snovideniia, Rarmyshlenia. Minsk: Kharvest. Online: http://lib.ru/PSIHO/JUNG/memdreamrefs.txt. Accessed December 30, 2015.

Leavy, Patricia. 2013. Fiction as Research Practice: Short Stories, Novellas, and Novels. Walnut Creek, CA: Left Coast Press.

Lestnitsa. Directed by Aleksei Sakharov. USSR, 1989. DVD.

Maslow, Abraham. 1954. Motivation and Personality. New York: Harper and Brothers.

Mayes, Frances. 2015. Under Magnolia: A Southern Memoir. New York: Broadway Books.

Midnight in Paris. Directed by Woody Allen. USA, 2014. DVD.

Nussbaum, Martha C. 1994. "Patriotism and Cosmopolitanism." Boston Review. October 1. Online: http://bostonreview.net/martha-nussbaum-patriotism-and-cosmopolitanism. Accessed: December 30, 2015.

Rosero, Evelio. 2013. 34 cuentos cortos y un gatopájaro. Bogotá: Destiempo.

Simmel, Georg. 1903. The Metropolis and Mental Life. Online: http://www.blackwellpublishing.com/content/bpl_images/content_store/sample_chapter /0631225137/bridge.pdf. Accessed: December 30, 2015.

The Final Cut. Directed by Omar Naim. USA, 2004. DVD.

Trubina, Elena. 2011. “Uchas' Vspominat': Vektory Issledovanii Pamiati.” In Iarskaia, V. and E. Iarskaia-Smirnova, eds. Vlast' Vremeni: Sotsialnye Granitsy Pamiati. Moscow: Tsentr Socialnoi Politiki i Gendernykh Issledovanii: 25-45.

Tuan, Y.-F. Escapism. The Johns Hopkins University Press, 1998.

Under the Tuscan Sun. Directed by Audrey Wells. USA, 2003. DVD.

Vizovskaia, Ekaterina. 2013. “Karelia. Perezagruzka i Emotsionalnye Orgazmy.” Blog entry August 1. Online: http://po-miru.com/mir/evropa/rossiya/zametka-rossiya/kareliyaperezagruzka-i-emotsionalnyie-orgazmyi/ . Accessed: December 30, 2015.

Vizovskaia, Ekaterina. 2014. "Kak Ia Pereekhala Zamuzh v Kolumbiiu.” Blog entry September 21. Online: http://po-miru.com/mir/yuzhnaya-amerika/kolumbiya/zametkakolumbiya/kak-ya-pereehala-zamuzh-v-kolumbiyu/ Accessed: December 30, 2015.

Vizovskaia, Ekaterina. 2015. "V Stranie Beriozok, Prokhladnogo Leta, Seliodki i OMS. Final." Blog entry September 22. Online: http://po-miru.com/mir/evropa/rossiya/zametkarossiya/v-strane-beryozok-prohladnogo-leta-selyodki-i-oms-chast-3/ Accessed: December $30,2015$. 